\title{
Література
}

1. Базелюк В. Г. Формування дослідницких умінь керівників ЗНЗ в системі післядипломної педагогічної освіти : дис. ... канд. пед. наук : 13.00 .04 / В. Г. Базелюк; Держ. вищ. навч. закл. «Ун-т менеджменту освіти» АПН України. - К., 2008. - 246 с. 2. Королюк С. В. Розвиток управлінської культури керівника загальноосвітнього навчального закладу в процесі підвищення кваліфікації : дис. ... канд. пед. наук : 13.00 .01 / С. В. Королюк. - Центр. ін-т післядиплом. пед. освіти АПН України. - К., 2005. - 231 с. 3. Мармаза О. І. Система підвищення функціональної компетентності керівників загальноосвітніх закладів : дис. ... канд. пед. наук : 13.00.01 / О. І. Мармаза. К., 1998. - 252 с. 4. Маслов В. И. Теория и методика педагогического руководства непрерывным повышением компетентности директора школы: дис. ... докт. пед. наук: 13.00.01. / В. И. Маслов. - К., 1991. - 429 с. 5. Мельник В. К. Підвищення управлінської кваліфікації керівника загальноосвітнього навчального закладу в системі післядипломної педагогічної освіти : дис. ... канд. пед. наук : 13.00 .01 / В. К. Мельник. Центр. ін-т післядиплом. пед. освіти АПН України. - К., 2003.- 220 с. 6. Нежинська О. О. Психологічні умови формування гендерної компетентності керівників загальноосвітніх навчальних закладів: автореф. дис. на здобуття наук. ступеня канд. психол. наук: 19.00 .07 / О. О. Нежинська. - ДВНЗ «Ун-т менеджменту освіти». - К., 2011. - 20 с. 7. Осколов П. В. Короткий нарис історії Чернівецького обласного інституту післядипломної педагогічної освіти / П. В. Осколов, В. Ф. Федорак, Н. І. Черкач. - Чернівці : Технодрук, 2005 - 62 с. 8. Пермінова Л. А. Розвиток професійних умінь керівника школи у системі курсової підготовки : дис. ... канд. пед. наук : 13.00 .04 / Л. А. Пермінова. - Центр. ін-т післядиплом. пед. освіти АПН України. К., 2002. - 203 с. 9. Попова Н. В. Організаційно-методичні засади консультативного забезпечення управлінської діяльності керівників загальноосвітніх навчальних закладів у регіоні: дис. ... канд. пед. наук : 13.00.06 / Н. В. Попова. - Ун-т менеджменту освіти АПН України. - К., 2008. - 222 с. 10. Протасова Н. Г. Післядипломна освіта педагогів: зміст, структура, тенденції розвитку / Н. Г. Протасова. - К., 1998. - 172 с.

Галина Бобрицька, Надія Кушлакова

\section{ХАРКІВСЬКИЙ ПЕРІОД НАУКОВО-ПЕДАГОГІЧНОЇ ДІЯЛЬНОСТІ ОЛЕКСАНДРА МИХАЙЛОВИЧА ЛЯПУНОВА (1857-1918)}

Бобрицька Г. С., Кушлакова Н. M. Харківський період науково-педагогічної діяльності Олександра Михайловича Ляпунова.

У статті узагальнено науково-педагогічні погляди О. М. Ляпунова в харківський період його життя; реконструйовано його діяльність як члена Харківського математичного товариства; визначено його ставлення до існуючої на той час системи навчання та контролю студентів військових i технічних навчальних закладів репетицій.

Ключові слова: Олександр Михайлович Ляпунов, Харківське математичне товариство, педагогічна діяльність, завдання ВНЗ, репетиція, мотивація.

Бобрицкая Г. С., Кушлакова Н. Н. Харьковский период научно-педагогической деятельности Александра Михайловича Ляпунова.

В статье обобщены научно-педагогические взгляды А. М. Ляпунова в харьковский период его жизни; реконструирована его деятельность в качестве члена Харьковского математического общества; определено его отношение к существующей в то время 
системе обучения и контроля студентов военных и технических учебных заведений системе репетиций.

Ключевые слова: Александр Михайлович Ляпунов, Харьковское математическое общество, педагогическая деятельность, задания вуза, репетиция, мотивация.

Bobrytska G. S., Kushlakova N. N Aleksander Mikhailovich Lyapunovs (1857-1918) Kharkov Period Of Scientific And Educational Activities.

The paper summarizes the Lyapunov's scientific and pedagogical views in Kharkov period of his life, reconstructs his activities at the Kharkov Mathematical Society, defines his relationship to the system of the student's training and supervision at military and technical schools (a system of rehearsals).

Key words: Aleksander Mikhailovich Lyapunov, the Kharkov Mathematical Society, teaching activities, the problem of high school, rehearsal, motivation.

Досліджуючи педагогічну діяльність Харківського математичного товариства (1879 р. заснування) загалом та його окремих членів зокрема, не можна залишити поза увагою таку видатну особистість, як Олександр Михайлович Ляпунов - видатний математик і механік кінця XIX - початку XX ст. Його життя та наукова діяльність досліджувались багатьма науковцями [1-6]. Однак не розкрито в літературі харківський період наукової діяльності О. Ляпунова. Його педагогічні погляди, їх становлення та розвиток в харківський період життя залишились поза увагою науковців.

Метою статті є вивчення й узагальнення наукової та педагогічної діяльності О. Ляпунова в період з 1885 р. по 1902 р.

О. Ляпунов народився 25 травня 1857 р. в Ярославлі. Його батько до переїзду в Ярославль багато років працював у Казанському університеті астрономом та директором астрономічної обсерваторії.

Початкову освіту О. Ляпунов отримав удома, а після смерті батька вступив в 1870 р. до гімназії Нижнього Новгорода одразу в третій клас. У гімназії він був одним 3 найкращих учнів і закінчив її в 1876 р. із золотою медаллю.

У 1880 р. закінчив фізико-математичний факультет Петербурзького університету. Під час навчання в університеті спочатку його наукові інтереси стосувалися хімії, яку викладав на той час студентам Д. Менделєєв. Згодом О. Ляпунов став більше цікавитися математикою, але лекції Д. Менделєєва продовжував відвідувати. Зацікавленість математикою пов'язана передовсім із тим, що О. Ляпунов слухав лекції з математичних дисциплін у видатних математиків П. Чебишева, К. Поссе, А. Коркіна.

Олександр Михайлович залишився при університеті та склав магістерські іспити, а в 1884 році захистив магістерську дисертацію «Про стійкість еліптичних форм рівноваги рідини, що обертається».

У наступному році О. Ляпунова було призначено доцентом на кафедру теоретичної механіки в Харківському університеті, де він працював з 1885 р. по 1902 р. Харківський період, за словами В. Стєклова, Олександр Михайлович згадував 3 особливим почуттям і називав цей час найщасливішим [3].

О. Ляпунов переїжджає до Харкова, отримавши запрошення обійняти вакантну посаду доцента кафедри механіки в Харківському університеті. Починаючи з осені 1885 р. і до 1890 р. О. Ляпунов один викладав усі лекції по кафедрі механіки, а також проводив практичні заняття зі студентами.

Серед особливостей лекцій Олександра Михайловича його учні називали: вміння оригінально викласти найскладніші наукові положення та супроводження лекцій власними коментарями і фактами, яких не було в підручниках. 
«Блискучий лектор, що розкрив перед своїми слухачами горизонти вершин науки, О. Ляпунов здобув виняткову повагу студентів. Із превеликою вимогливістю він готувався до лекцій. Складені ним літографовані записки та вказівки вирізняються оригінальністю, високим науковим рівнем викладу матеріалу. А деякі з них містять факти, яких не було в інших підручниках. Ці вказівки і записки можна вважати самостійними науково-методичними роботами» [5].

За перші два роки викладання О. Ляпунов написав такі курси лекцій: кінематика 155 сторінок, динаміка матеріальної точки - 156 сторінок, статика - 124 сторінки, динаміка систем матеріальних точок - 415 сторінок, теорія тяжіння - 75 сторінок, основна теорія тіл, що деформуються, та гідростатика - 128 сторінок [2].

О. Крилов у своїх спогадах виокремив такі особливості літографованих курсів О. Ляпунова:

1. Автор викладав механіку, як галузь математики, а не фізики, залишаючи поза увагою іiі прикладний характер, бездоганна строгість доведень висувалася ним як головна вимога. У цьому аспекті багато положень розроблено особисто автором та не представлено в інших курсах.

2. У курсі відсутні будь-які проміжні викладки; вони замінені вказівкою послідовності необхідних дій або перетворень та результатом, який студенти мають отримати.

О. Ляпунов, здійснюючи педагогічну i наукову діяльність у Харківському університеті, багато уваги приділяв організації та роботі кабінету практичної механіки задля його функціонування за призначенням, оскільки був глибоко переконаний «у великій користі кабінету в справі викладання» [4].

Як викладач Харківського імператорського університету, а згодом і Харківського технологічного інституту, О. Ляпунов опікувався питаннями педагогічного характеру та проблемами викладання математики та механіки.

О. Ляпунов визначав основним завданням вищого навчального закладу виховання класу людей освічених загалом і за певною спеціальністю, до якої вони мають здібності та інтерес. Умовами, які б забезпечили розв'язання цього завдання, є мотивація та організація самостійної навчальної діяльності студентів. Мотивацією студентів може бути лише інтерес до науки, розуміння іiі користі, а не зовнішні причини. На основі цього, навчання у ВНЗ не може носити примусовий характер. Уся система викладання має бути побудована так, щоб студенти мали повну можливість самостійно і серйозно розбиратися та вникати у цікаві їм науки.

У кінці XIX ст. у технічних і військових вищих навчальних закладах набула широкого розповсюдження нова форма організації навчального процесу, у якій одним із методів періодичного контролю були «обов'язкові репетиції». Вони полягали в тому, що учень протягом 6 днів поглиблено вивчав програму з одного предмета. По закінченню строку учень складав іспит викладачу, отримував оцінку та починав вивчати інший предмет.

Провідні викладачі виступали проти такої системи контролю. Серед них і О. Ляпунов, який виокремив такі недоліки цієї системи:

- механічне заучування теоретичного матеріалу не пов'язаного логічно. Спочатку повне занурення студента в один предмет протягом 6-ти днів, потім відкидання вже вивченого та занурення в зовсім інший теоретичний матеріал;

- постійне нервове напруження студента, по-перше, через неможливість у короткий термін настільки вивчити предмет, щоб по закінченню строку відповідати на будь-яке $з$ поставлених питань, по-друге, студент не міг покинути зовсім інші заняття; 
- механічне заучування та постійне нервове напруження призводять до притуплення інтересу до науки та вимагають від студента для отримання гарної оцінки вдаватися до списувань, підказок тощо;

- змінюється мотивація до навчання. Мотивацією для навчання стає не інтерес до науки, а необхідність отримати оцінку.

Відзначаючи недоліки репетицій, О. Ляпунов пропонує замість них проводити більше практичних занять, на яких би вирішувались поточні питання студентів.

Окрім викладацької діяльності, Олександр Михайлович приділяє багато часу й громадсько-науковій. На той час при Харківському університеті вже існувало та розвинуло свою діяльність Харківське математичне товариство (ХМТ). Створене в 1879 році суто математичне товариство стало другим у Російській імперії після Московського математичного товариства. Головою товариства був К. Андреєв. Разом із початком роботи в Харківському університеті О. Ляпунов вступає до Харківського математичного товариства та бере активну участь у його діяльності з перших днів членства.

Робота О. Ляпунова в ХМТ охоплює 33 роки його життя, протягом яких він виконував різноманітні обов'язки й обіймав різні посади від дійсного члена товариства до його голови й почесного члена:

- 31885 по 1891 р. він дійсний член товариства;

- 31891 по 1899 р. обіймає посаду товариша голови товариства під час головування К. Андреєва;

- з 1899 по 1902 р. - голова товариства;

- 31902 року - почесний член товариства [7].

Як дійсний член товариства О. Ляпунов бере активну участь у роботі ХМТ: систематично доповідає результати своїх наукових досліджень, бере участь у дебатах 3 приводу повідомлень інших членів товариства, виголошує доповіді інших науковців.

Як член розпорядчого комітету (товариша голови та голови) О. Ляпунов, крім наукової роботи, опікується організаційною діяльністю товариства (організовує роботу засідань загальних зборів та засідань Ради) та вирішує питання видавничої діяльності (рецензує статті, править коректури вже готових до видання робіт, виконує обов'язки редактора «Сообщений Харьковского математического общества»).

О. Ляпунов бере активну участь у науковій роботі товариства. За період свого членства в товаристві він зробив на засіданнях 30 доповідей, які можна поділити на три основні групи:
- доповідав
статті колег
(О. Маркова,
П. Сомова,
М. Жуковського,

I. Мещерського, Д. Бобилєва, Д. Граве);

- презентував результати своїх власних наукових досліджень 3 астрономії, теорії стійкості руху, теорії інтегрування систем диференціальних рівнянь, теорії потенціалу, теорії ймовірностей тощо;

- пропонував свої розв'язки проблем, розглянутих в роботах інших членів товариства [7].

Із загального кола наукових інтересів О. Ляпунова роботи про стійкість руху принесли йому всесвітню відомість, оскільки $є$ фундаментальними не лише в галузі математики, але й у тих розділах механіки та фізики, де вивчаються коливання механічних і фізичних систем. Результати досліджень О. Ляпунова відповідали також нагальним потребам астрономів того часу, які працювали над питаннями астрофізики та небесної механіки.

У 1891 р. в «Сообщениях Харьковского математического общества» була опублікована робота «Про стійкість руху в одному окремому випадку задачі про три 
тіла». Це була друга робота науковця із циклу робіт про стійкість руху. У ній автор розглядає стійкість деякої спеціальної системи лінійних рівнянь другого порядку 3 періодичними коефіцієнтами, обчислює дві постійні, аналогічні до заданої постійної величини А, наводить два способи для наближення обчислення цих постійних та розв'язує деякі питання про стійкість. Короткий аналіз цієї роботи зроблено в статті Н. Меркулової та П. Соколова [6].

У 1892 р. Харківське математичне товариство видає його велику працю «Загальна задача про стійкість руху». Після захисту ії в цьому ж році О. Ляпунов, отримавши ступінь доктора, обіймає посаду ординарного професора в Харківському університеті.

Використовуючи особисті зв'язки, він залучив до роботи в товаристві М. Лагутинського (1901 р.), Е. Коссерат (1902 р.), А. Котельникова (1902 р.).

У 1900 році О. Ляпунова було обрано членом-кореспондентом Петербурзької АН, а в 1901 - ординарним академіком. У зв'язку з тим, що ординарні академіки зобов'язані були постійно перебувати в Петербурзі, навесні 1902 р. О. Ляпунов виїжджає з Харкова до Петербургу, де він повністю присвятив себе науковій діяльності.

У 1902 році у зв’язку з від’їздом О. Ляпунова було скликане термінове засідання математичного товариства. Визнаючи заслуги О. Ляпунова перед товариством, його активну участь у діяльності ХМТ Олександра Михайловича обрали почесним членом товариства.

У 1917 р. через хворобу дружини він переїжджає до Одеси. Сім'я Ляпунових опиняється в скрутному матеріальному становищі та не має можливості виїхати до Петербургу з окупованої під час Першої світової війни Одеси.

У серпні 1918 р. О. Ляпунова запрошують читати лекції до Новоросійського Університету (Одеса). У листопаді 1918 р. О. Ляпунов трагічно загинув, залишивши після себе значний науково-педагогічний спадок.

Успішність педагогічної діяльності викладача визначається не лише його особистою працею та методичним доробком, а передовсім досягненнями його учнів. Серед учнів О. Ляпунова був відомий математик і механік, талановитий педагог В. Стєклов.

Проведене дослідження та опрацьований матеріал дозволили нам узагальнити науково-педагогічні погляди О. Ляпунова в харківський період його життя; реконструювати його діяльність у Харківському математичному товаристві загалом та педагогічну діяльність зокрема; з'ясувати невідомі раніше факти щодо поглядів О. Ляпунова до організації навчального процесу, зокрема так званих «репетицій».

\section{Література}

1. Бахмутская Э. Я. Математика в Харьковском университете. Харьковское математическое общество / Э. Я. Бахмутская // История отечественной математики. - К., 1967. - Т. 2. - С. 460-472. 2. Бузескул В. П. Александр Михайлович Ляпунов и Харьковский университет 80-х годов. Страничка из личных воспоминаний: Речь, произнес. в заседании ХМО, посвящ. памяти акад. А. М. Ляпунова / В. П. Бузескул// Учен. зап. Высш. шк. Отд. гуманит.-обществ. наук. - 1922. - Т. 2. - С. 117-120. 3. Крылов А. Н. Мои воспоминания [Електронний ресурс] / А. Н. Крылов. - М. : Изд-во АН СССР, 1963. - Режим доступу: http://militera.lib.ru/memo/russian/krylov_an/index.html. 4. Ляпунов Александр Михайлович (1857-1918): Библиогр. указ.: Биогр. очерк и обзор осн. науч. результатов; Труды А. М. Ляпунова. Лит. о жизни и деятельности ученого / Н. Н. Кизилова; сост.: С. Б. Глибицкая, С. Р. Марченко; науч. ред. Н. Н. Кизилова; Библиогр. ред. Ю. Ю. Полякова. - Х., 2007. - 73 с. 5. Меркулова Н. М. О научном наследии А. М. Ляпунова / Н. М. Меркулова, П. Б. Соколов // ИМЕН. - 
1970. - Вып 9. - С. 90-109. 7. Протоколы заседаний Харьковского математического общества за 1885-1902 гг.// Сообщения Харьковского математического общества. 1886-1903 гг. 6. Цыкало А. Л. А. М. Ляпунов / А. Л. Цыкало - М. : Наука, 1988. - 246 с.

\section{АНАЛІЗ ФІЛОСОФСЬКО-СВІТОГЛЯДНОЇ ТА КУЛЬТУРОЛОГІЧНОЇ СПЕЦИФІКИ ПРОЦЕСУ НАВЧАННЯ ФІЛОЛОГІЧНИХ ДИСЦИПЛІН У КОНТЕКСТІ РОЗВИТКУ РЕФЛЕКСИВНИХ УМІНЬ}

Герасимова О. І. Аналіз філософсько-світоглядної та культурологічної специфіки процесу навчання філологічних дисциплін у контексті розвитку рефлексивних умінь.

У статті аналізується філософсько-світоглядна та культурологічна специфіка філологічних дисциплін; з'ясовується специфіка навчання філологічних дисциплін в умовах педагогічного університету, обгрунтовується необхідність реалізації єдності процесуального та змістового складників як у філологічному, так і в соціальнофілософському аспектах.

Ключові слова: рефлексія, рефлексивні уміння, філологічні дисципліни, самоосвіта, освітній процес.

Герасимова О. И. Анализ философско-мировоззренческой и культурологической специфики процесса обучения филологических дисциплин в контексте развития рефлексивных умений.

В статье анализируется философско-мировоззренческая и культурологическая специфика филологических дисциплин, определяется специфика обучения филологических дисциплин в условиях педагогического университета, обосновывается необходимость реализации единства процессуального и содержательного компонентов как в филологическом, так и в социально-философском аспектах.

Ключевые слова: рефлексия, рефлексивные умения, филологические дисциплины, самообразование, образовательный процесс.

Herasimova O. I. Analysis of philosophical and ideological and cultural specificity of learning process of philological disciplines in the context of development skills of reflection.

The article examines the philosophical and ideological and cultural specificity of philological disciplines, it turns out, the specifics of teaching philological disciplines under pedagogical university, identifies the need for the implementation of procedural and substantive unity as components in a philological and socio-philosophical aspects.

Key words: reflection, skills of reflection, philological discipline. self-education, educational process.

Нова парадигма педагогічної освіти розробляється на основі аксіом, що формуються на пріоритетах унікальності, амбівалентності особистості, опосередкованості iii розвитку. На тлі затвердження соціокультурних цінностей професійно-педагогічної підготовки студентів вищої школи на перший план висуваються завдання формування професійно-педагогічного світогляду студентів, фундаментом якого є варіативність, суб'єктність, особистий рефлексивний досвід. Цей вектор наукової та науково-практичної діяльності спрямовує зусилля викладачів на вироблення у студентів за період навчання у вищому педагогічному навчальному закладі певної системи якостей та властивостей, яка становитиме основу 